\title{
Revised Long-term Creep Rates on the Hayward Fault, Alameda and Contra Costa Counties, California
}

By

James J. Lienkaemper ${ }^{1}$

and

Jon S. Galehouse ${ }^{2}$

\section{Open-File Report 97- 690}

This report is preliminary and has not been reviewed for conformity with U.S. Geological Survey editorial standards or with the North American stratigraphic code. Any use of trade, product, or firm names is for descriptive purposes only and does not imply endorsement by the U.S. Government.

${ }^{1}$ U.S. Geological Survey, 345 Middlefield Rd., Menlo Park, CA 94025

${ }^{2}$ San Francisco State University, 1600 Holloway Ave., San Francisco 94132 


\section{Abstract}

Although the Hayward fault is a source of major earthquakes, it also creeps or slips aseismically, and has done so steadily for several decades (certainly since 1921 and probably since 1869). Most of the fault creeps between 3 and $6 \mathrm{~mm} / \mathrm{yr}$, except for a 4 - to 6-km-long segment near its south end that creeps at about $9 \mathrm{~mm} / \mathrm{yr}$. We present results of our recent surveys to recover angles and deflection lines established across the fault in the 1960s and 1970s, but unmonitored since. We have added data from more offset cultural features to the long-term creep rate data set and made substantial improvements to the analytical method used to compute offsets. The revised creep rate values improve our knowledge of spatial and temporal variation along the fault. The more accurate revised data has reduced the estimate of the average creep rate along most of the fault from $5.1 \mathrm{~mm} / \mathrm{yr}$ to $4.6 \mathrm{~mm} / \mathrm{yr}$. Creep rates in the $9 \mathrm{~mm} / \mathrm{yr}$ section near the south end have remained the same.

\section{Introduction}

The approximate distribution of long-term creep rate along the Hayward fault is well known [Lienkaemper and others, 1991]. The purpose of this paper is to update Lienkaemper and others [1991] with both (1) a sizeable body of new data and (2) some significantly revised creep rates derived from offset cultural features using improved analysis. The intent of this report is to present creep rates ending before the 17 October 1989 Loma Prieta earthquake (LPEQ), because stress changes associated with that event seemed to have strongly reduced creep rates along the Hayward fault in the Fremont area ( $\mathrm{km} 58$ to km 68 in Figure 1) for a few years, and possibly reduced some creep rates to the north as well [Galehouse, 1995; Galehouse, 1997; Lienkaemper and others, 1997]. In some cases long-term creep rates shown in Table 1 do unavoidably include some time after LPEQ, but we generally judge the event's effect to be negligible in proportion to the much greater time sampled before the event. We do not intend to demonstrate the effects of 
LPEQ on creep rate in this report, because short-term creep rates are subject to much greater uncertainties than are long-term rates [Langbein and Johnson, 1997]. We believe it is more useful to gather post-earthquake creep data for a few more years and then compare decade-long, postLPEQ to this earlier long-term data.

We begin by describing improvements to the analysis of offset cultural features (Figure 2) and the results (Table 1). We then discuss new surveys on angle and deflection arrays (Table 1), and show a selection of the data in Figure 3 . Locations in the text, table, and figures are described in terms of a detailed kilometer grid shown in Lienkaemper [1992] and keyed to the numbered crosses in Figure 1. We present only a brief discussion and summary here because we intend this report as a presentation of detailed data to be followed by a summary report elsewhere.

\section{Analysis of offset cultural features and results}

Field procedures, selection criteria, and general analytical methodology were given in Lienkaemper and others [1991] and will not be repeated here. Three significant changes were made in our analytical methods, which we used to reanalyze all appropriate offset features. For completeness we show all offset features in Figure 2 and Table 1, including those that did not need changing. The first and probably most significant change is the elimination of assumed but uncorroborated secondary fault traces. This problem came to our attention during our analysis of deflection line data at km 43.22 ([D] in Figure 2). In Lienkaemper and others [1991] an additional trace was inferred here, but its existence is not sustained by the deflection data. The result was an overestimation of slip rate by about $1 \mathrm{~mm} / \mathrm{yr}$. Other such interpreted traces have been eliminated unless corroborated by independent evidence, or as in the case of $\mathrm{km} 18.43$, the uncertain existence of multiple traces is included in the overall estimated error for the site.

The second change is to assume, for purposes of multiple linear regression (MLR), that fewer points reflect deformation in the fault zone. We now account more rigorously for the original waviness or irregularity in the as-built shape of the cultural feature. For example, the curb offset at 
Banks Drive (Fig. 2, km 1.90 [C]) requires consideration of its original waviness to make a reasonable interpretaion of fault zone width. In theory this could be done by a statistical cutoff of $2 \sigma$ error in regression fit, which is now the rule-of-thumb used by us in interpreting these features. That is, points within $2 \sigma$ of best fit are generally not excluded from the final fit. However, because this is necessarily an iterative procedure, it is difficult to eliminate the human interpreter from the process because the value of $2 \sigma$ computed by MLR becomes large as the interpreter permits more values in the fault zone into the MLR analysis and an additional decision criterion is needed. In practice this distinction is usually simple for the interpreter; some points are distinctly in the fault zone, while others may also be consistent with both minor deformation and with general amount of irregularity of the feature. We now generally keep such ambiguous points in the analysis, which tends to slightly reduce the amount of computed offset. We did not automate this process although doing so might further improve the consistency of the results.

A third correction also relates to the original irregularity of the feature, but it rarely applies. An example is at 4.50 (Fig. 2, 4.50 [C]) where the MLR data is clearly falsified by a gross irregularity in the feature, and a human interpreter must match the offset feature across the fault.

The revised creep rates resulting from these changes in analytical assumptions do not differ greatly from those reported in Lienkaemper and others [1991], but where rates did change they tend to be somewhat lower. Where these revised rates can be compared to rates from alinement array data, agreement tends to be improved. The highest rates, $\sim 9 \mathrm{~mm} / \mathrm{yr}$, in southern Fremont were not significantly affected by these new procedures.

\section{Analysis of alinement arrays and results}

Methodology for alinement array measurement is described in Galehouse and others [1982], Harsh and Burford [1982], and Wilmesher and Baker [1987]. Most arrays reported on here depend on measurement of angle changes across the fault (items coded as A, in Table 1). A few arrays are deflection arrays that measure creep as the increasing misalinement of a line of marks 
across the fault, that were either originally straight or of a known original configuration $(\mathrm{D}$, in Table 1). A few other arrays or nets are of the trilateration type as described in Prescott and Lisowski [1983] that measure creep using changes in length of fault-crossing lines (T, in Table 1). Many arrays were established and monitored in the 1960s and 1970s by cities and other entities, but monitoring generally lapsed in the late 1970s and 1980s. In the late 1980s and early in 1990s,

we recovered many such arrays for this study. We show our results in Table 1 and in Figure 3 we have plotted creep versus time for a selection of the sites having about a decade or more of creep data with multiple surveys. Where multiple surveys were available we calculated the creep rates in Table 1 by linear regression of all data.

\section{Discussion}

Although the spatial distribution of creep rate remains qualitatively similar to that shown in Lienkaemper and others [1991], the average of all creep rates in Table 1 north of the fast (9 $\mathrm{mm} / \mathrm{yr}$ ) section has generally decreased by about $0.5 \mathrm{~mm} / \mathrm{yr}$ over the same part of the fault from the previous report (from an average of $5.1 \pm 0.9 \mathrm{~mm} / \mathrm{yr}$ on 31 observations, dropping to $4.6 \pm$ $0.8 \mathrm{~mm} / \mathrm{yr}$ on 48 observations). Although much of the change comes from improved methodology in analyzing offset cultural features, a significant improvement also derives from having recovered many older arrays, thereby allowing us to determine multi-decade, surveyed creep rates for these locations.

An initial goal of our investigation was to search for evidence of significant variations in creep rate over time. Lienkaemper and others [1991] suggested that creep rate on the fault appears to be constant over decades. Other than the effects of LPEQ, our investigation tends to confirm the assumption that creep does not vary significantly with time when comparing periods of a decade or more. At km 43.22 (Rose St, Hayward) we see excellent agreement over many decades. Likewise at km 1.82 and 1.90 (near Point Pinole) agreement is strong over decades. The BART tunnel data ( $\mathrm{km} 20.28)$ suggests a steady rate over about two decades. Southern Fremont data (km 
63 to 67 ) also tend to support relatively steady creep over many decades. Although the cultural offsets have sizeable uncertainties, they generally support the idea of steady long-term creep rates everywhere on the fault within the limits of computed errors.

\section{Acknowledgments}

The National Earthquake Hazards Program of the U.S.G.S. funded both U.S.G.S. (\#7460-11640) and S.F.S.U. (\#1434-94-G2420). We thank many student assistants for their conscientious efforts in recovering these old arrays, especially Carolyn Garrison, Oliver Graves and Theresa Hoyt. For their assistance in recovering old arrays and construction dates on cultural features, we also thank land surveyor D. J. Russell, the city governments of Fremont, Hayward \& Oakland, East Bay Municipal Utilities District, and Bay Area Rapid Transit District (especially W. Hazelwood). 


\section{References}

Galehouse, J. S., 1995, Theodolite measurements of creep rates on San Francisco Bay region faults: U.S. Geological Survey Open-File Report 95-210, p. 335-346.

Galehouse, J. S., Effect of the Loma Prieta earthquake on fault creep rates in the San Francisco Bay region, U.S. Geological Survey Profess. Pap.1550D, 193-207, 1997.

Galehouse, J. S., Brown, B. D., Pierce, B. and Thordsen, J. J., 1982, Changes in movement rates on certain East Bay faults, California Division of Mines and Geology Special Publication, v. 62, p. $239-250$

Harsh, P. W., and R. O. Burford, 1982, Alinement array measurements of fault slip in the eastern San Francisco Bay area, California: California Division of Mines and Geology Special Publication, v. 62, p. 251-260.

Langbein, J. and Johnson, H., 1997, Correlated errors in geodetic time series: implications for time-dependent deformation: Journal of Geophysical Research, v. 102, p 591-603.

Lienkaemper, J. J., Borchardt, G. , and Lisowski, M., 1991, Historic creep rate and potential for seismic slip along the Hayward fault, California: Journal of Geophysical Research, v. 96, no. B11, p. 18,261-18,283.

Lienkaemper, J. J., Galehouse, J. S. , Simpson, R. W. , 1997, Creep response of the Hayward fault to stress changes caused by the Loma Prieta earthquake, Science, v. 276, p. 2014- 2016.

Lienkaemper, J. J., 1992, Map of recently active traces of the Hayward fault, Alameda and Contra Costa Counties, California: U.S. Geological Survey Miscellaneous Field Studies Map MF2196, map scale 1:24,000, 13 p.

Prescott, W. H., and M. Lisowski, 1983, Strain accumulation along the San Andreas fault system east of San Francisco Bay, California: Tectonophysics, v. 97, p. 41-56. 
Wilmesher, J. F., and Baker, F. B.,1987, Catalog of alinement array measurements in central and southern California from 1983 through 1986: U.S. Geological Survey Open-File Report 87280, 157 p. 


\section{Figure Captions}

Figure 1. Location of sites yielding creep rates shown in Table 1.

Figure 2. Fault creep viewed transverse to the fault. For offset cultural features $[\mathrm{C}]$ and deflection

lines [D] in Table 1, we show models of accumulated creep versus distance along feature.

Dashed lines show multiple linear regression (MLR) best fit to data. Rectangles or ovals with curved corners indicate surveyed points in the fault zone excluded from the regression. The height of curved boxes also indicate interpretative fits to data, that in a few cases differ substantially from the MLR fit.

Figure 3. Fault creep versus time. Triangles represent observations on alinement arrays. At km

20.28, initial surveys were on a 400-m wide deflection array and later (inverted triangles) on a 90-m wide array (see also Figure 2). At km 44.56 first four surveys were deflection arrays and later data are from angle changes. At km 66.3 (NE curb of Camellia Drive) offset in 1983 from R.O. Burford, unpublished data, 1983. 


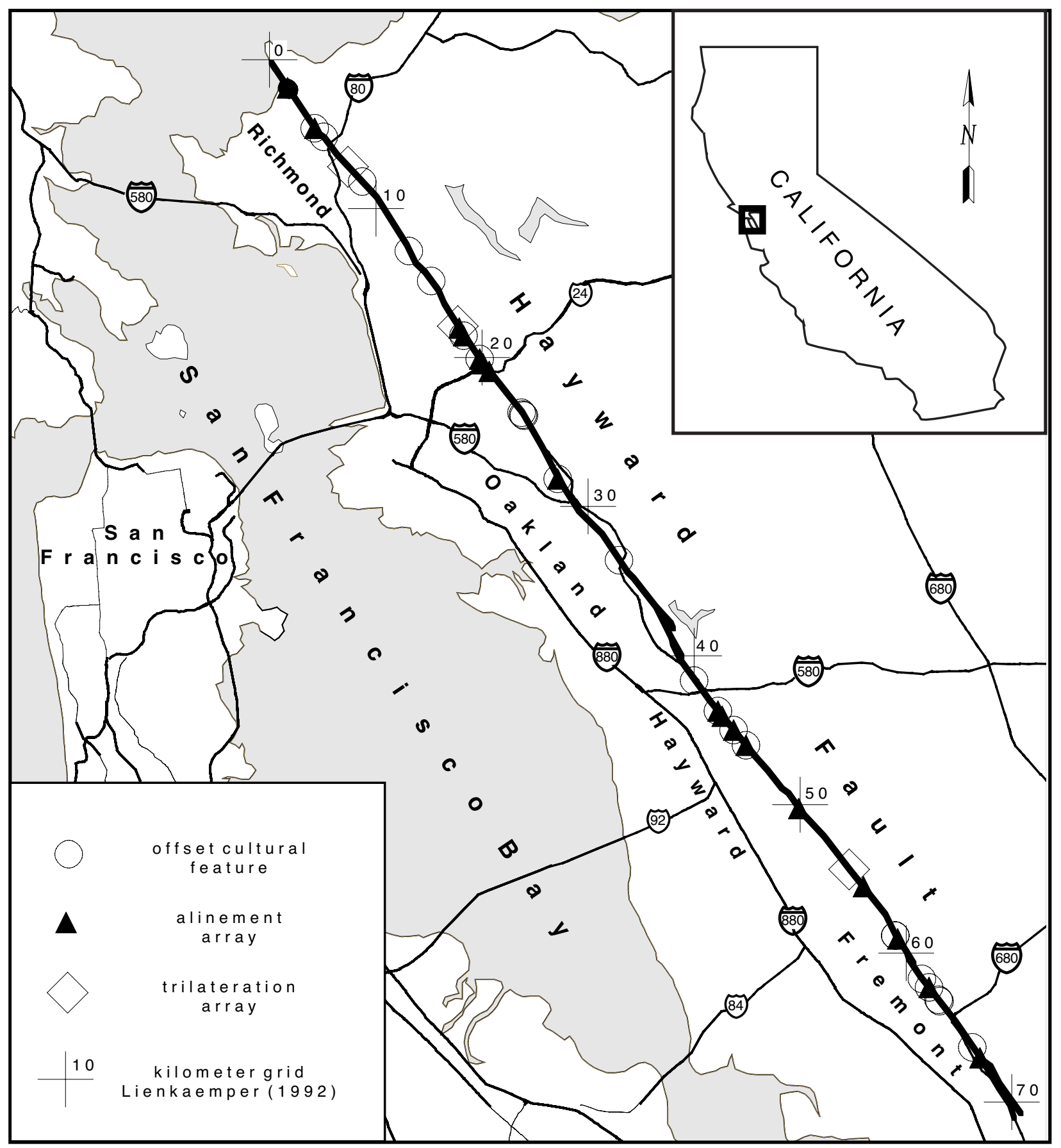

Figure 1 


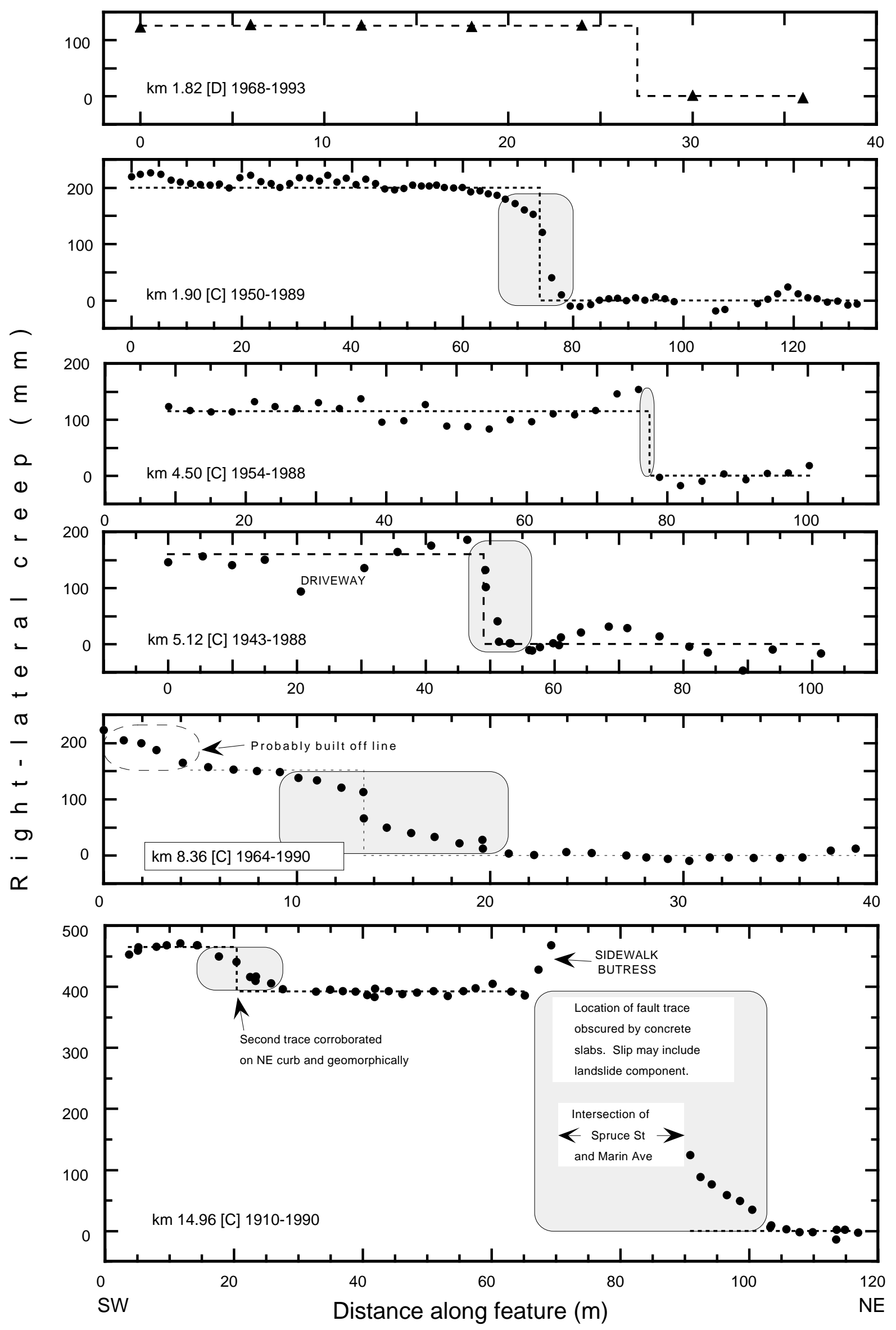

Figure 2 


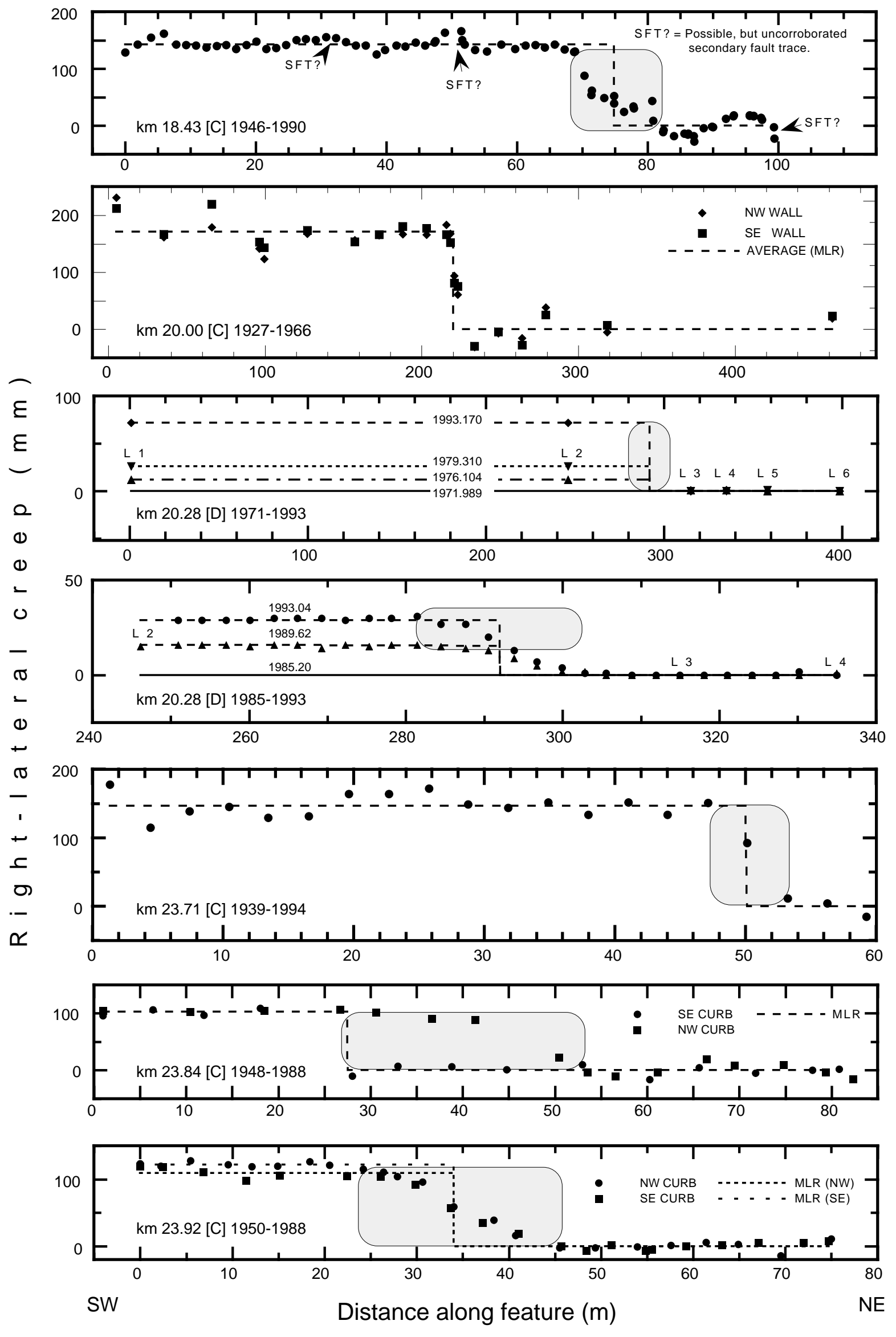

Figure 2 (continued) 


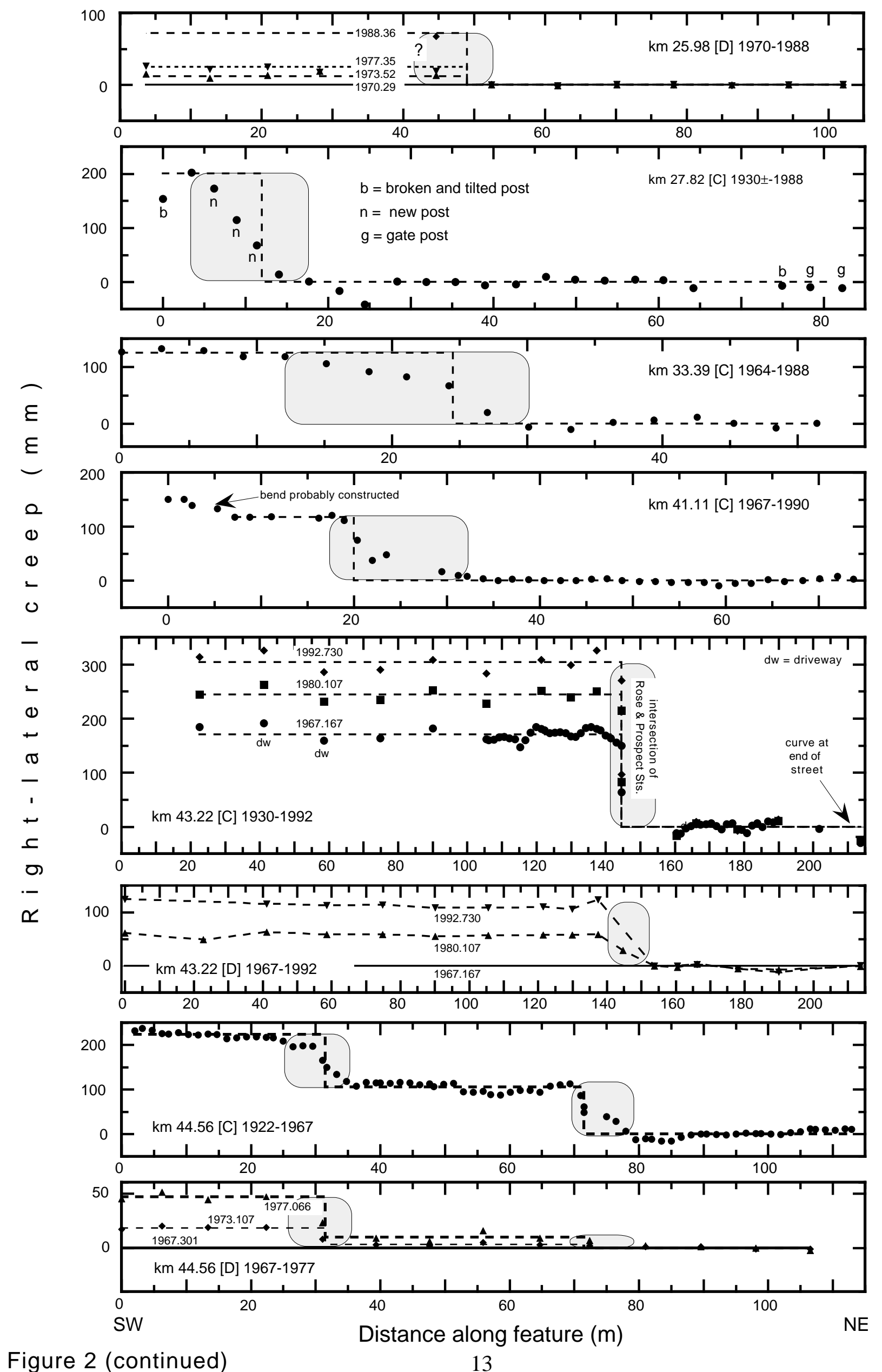

Figure 2 (continued) 

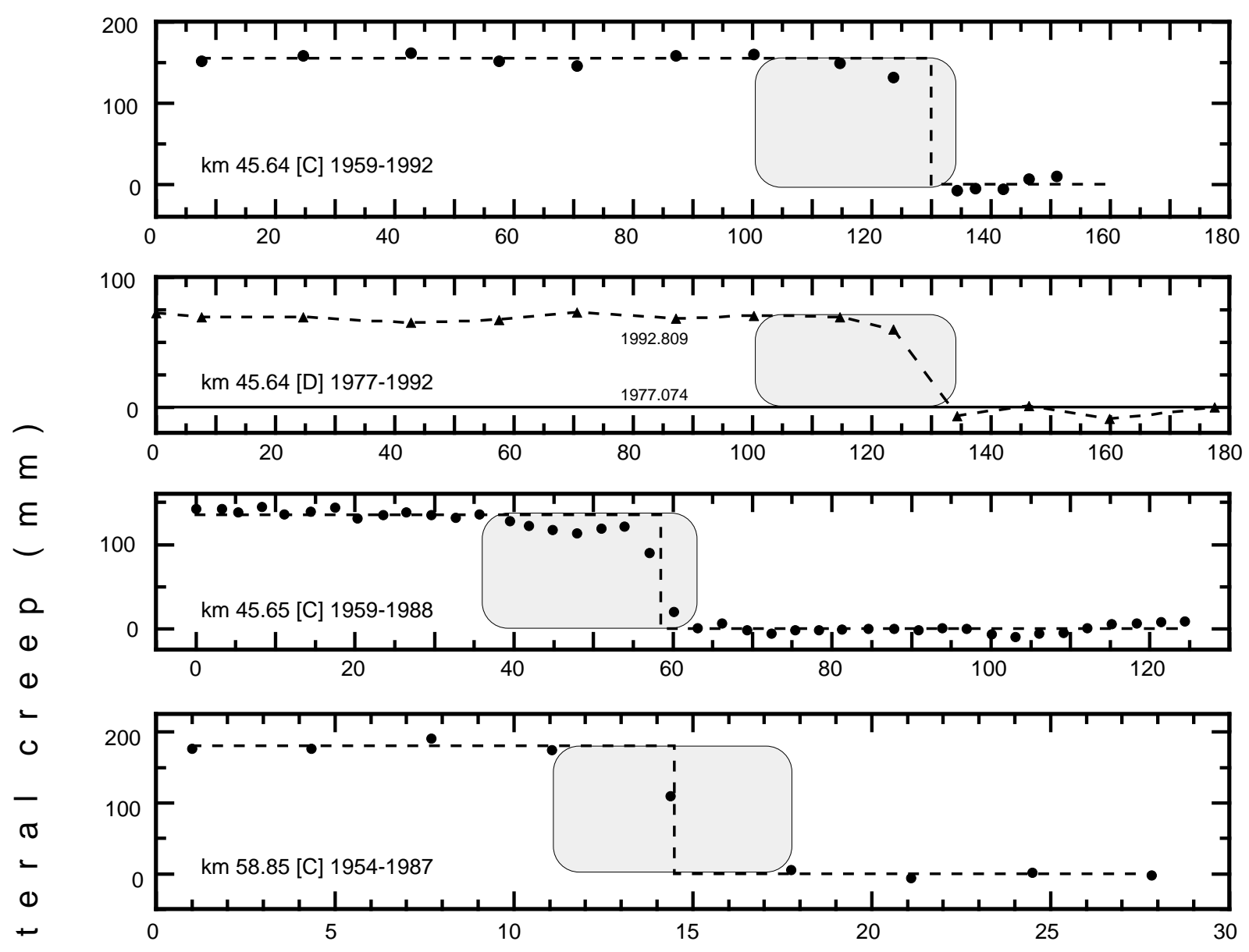

๘

-

$+$

ᄃ

o

-

$\llbracket$
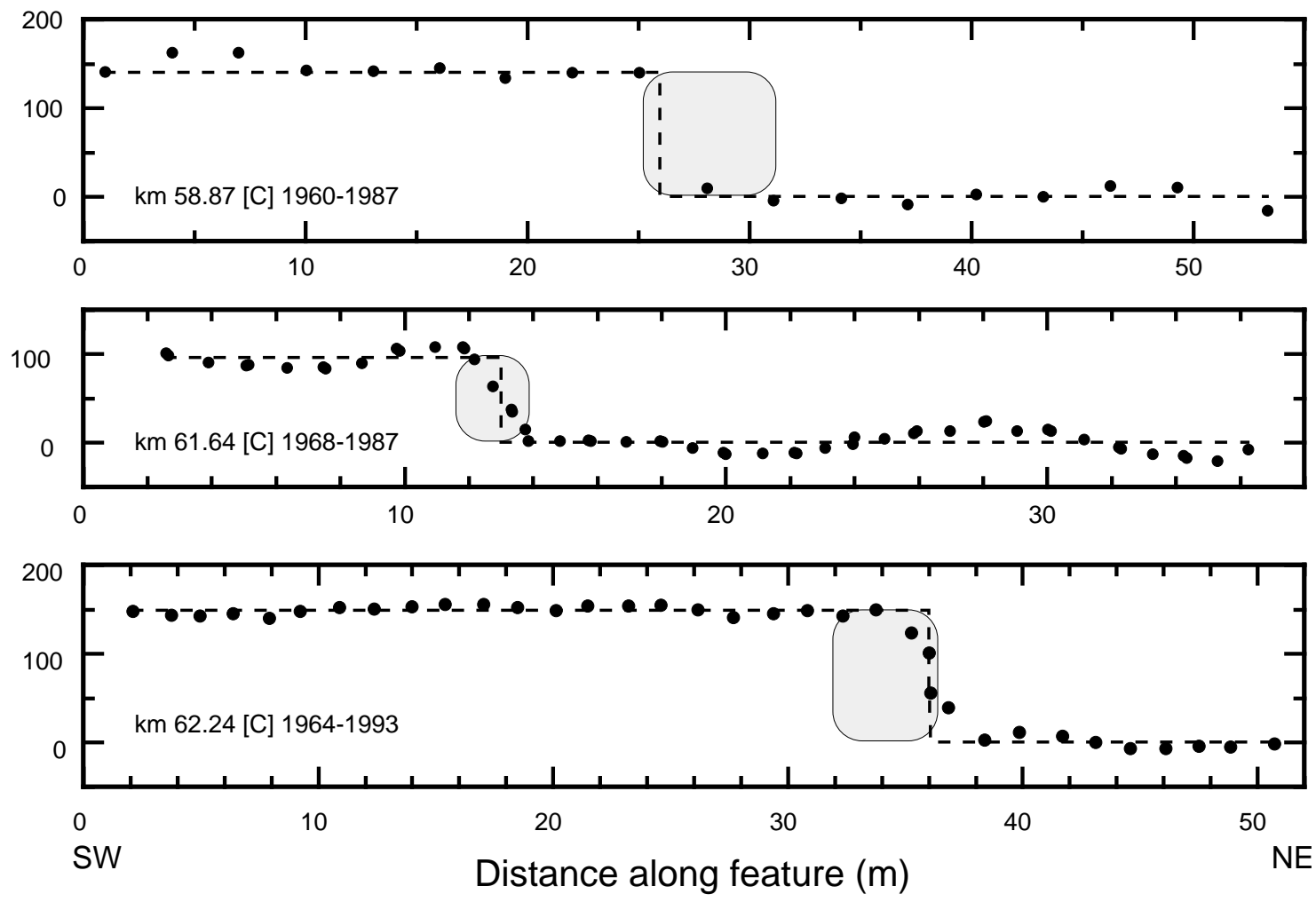

Figure 2 (continued) 


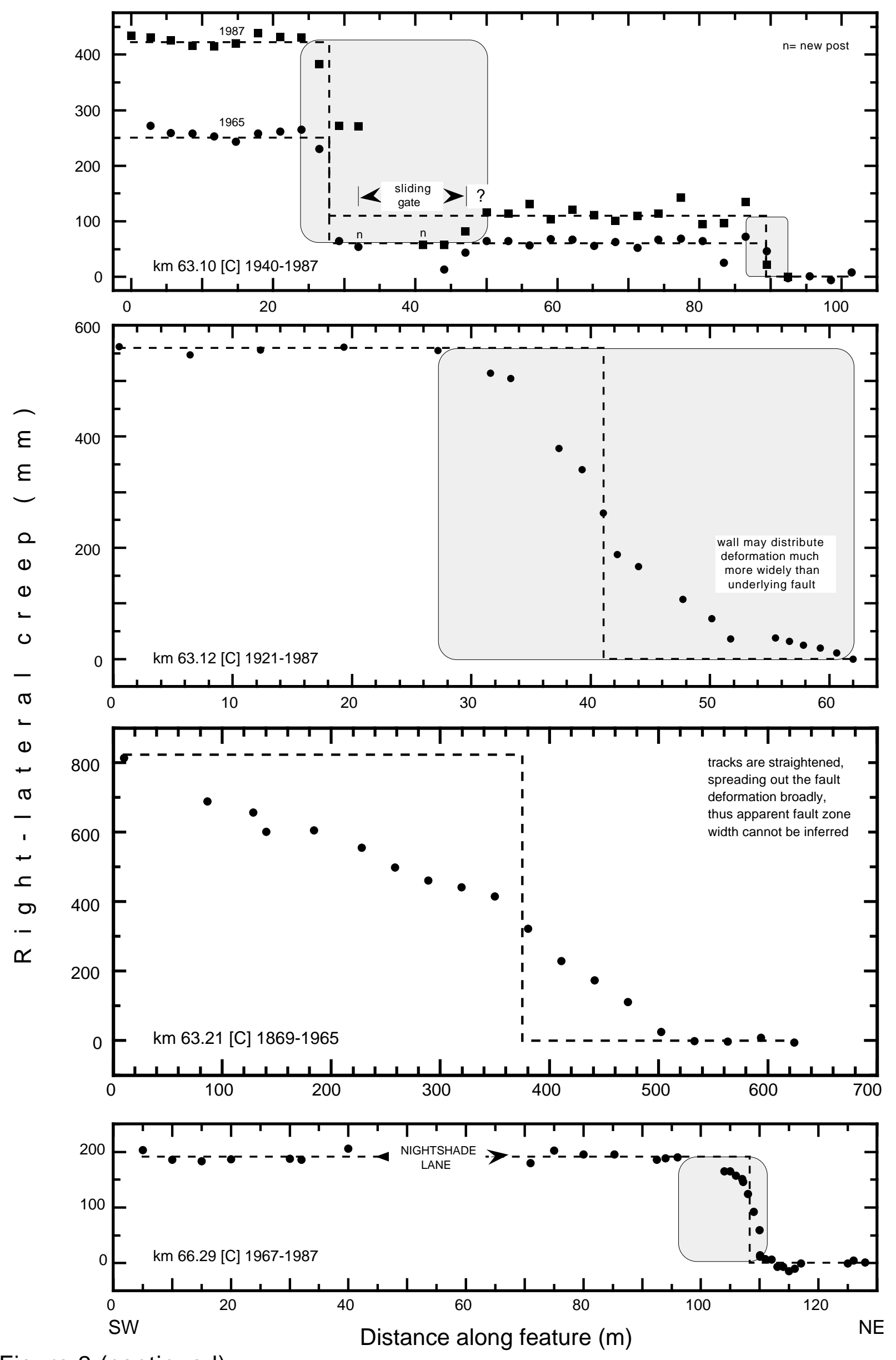

Figure 2 (continued) 

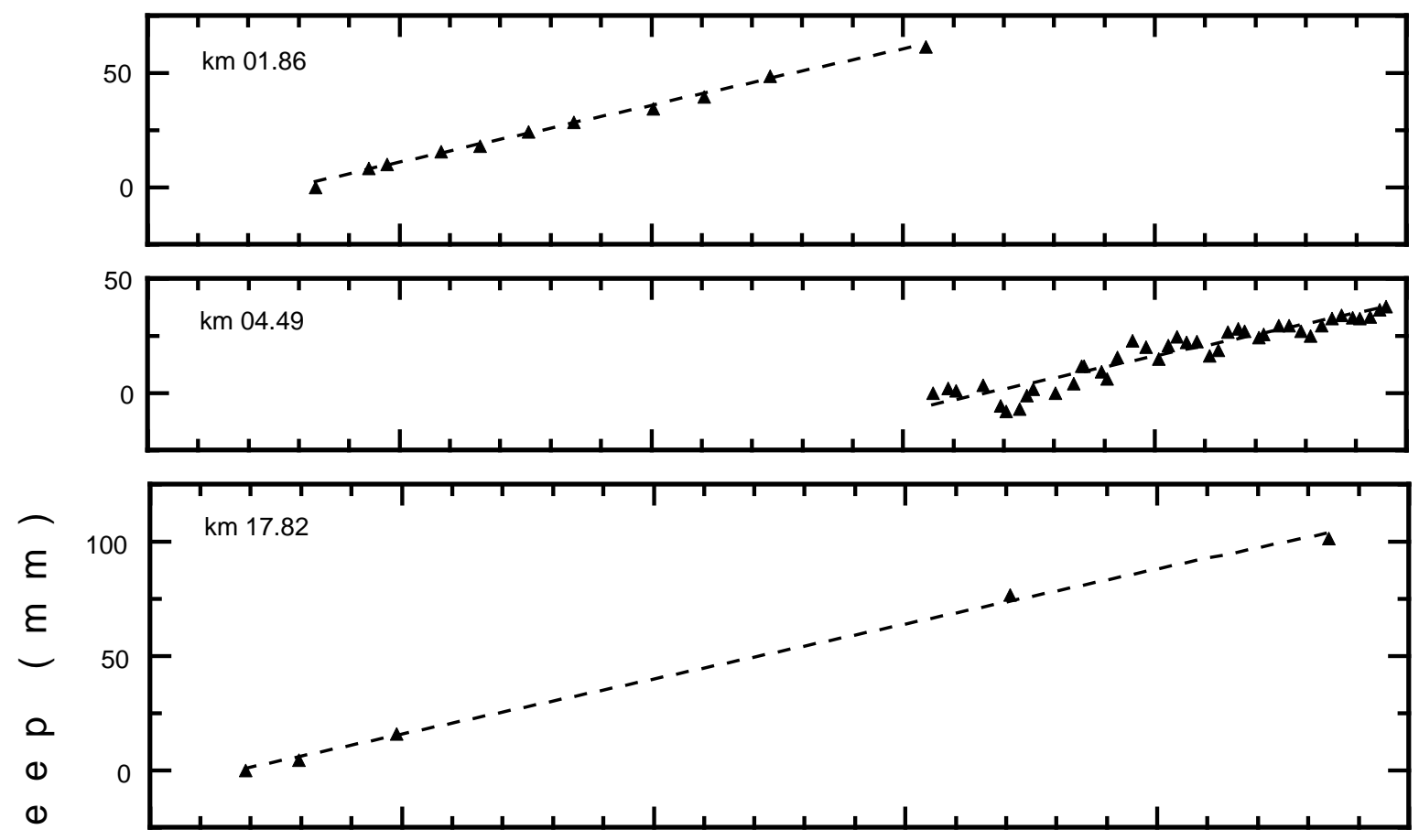

1

0

$-$

ช

1

0

$+$

ఠ

,

$+$

ᄃ

o

ฯ

Figure 3
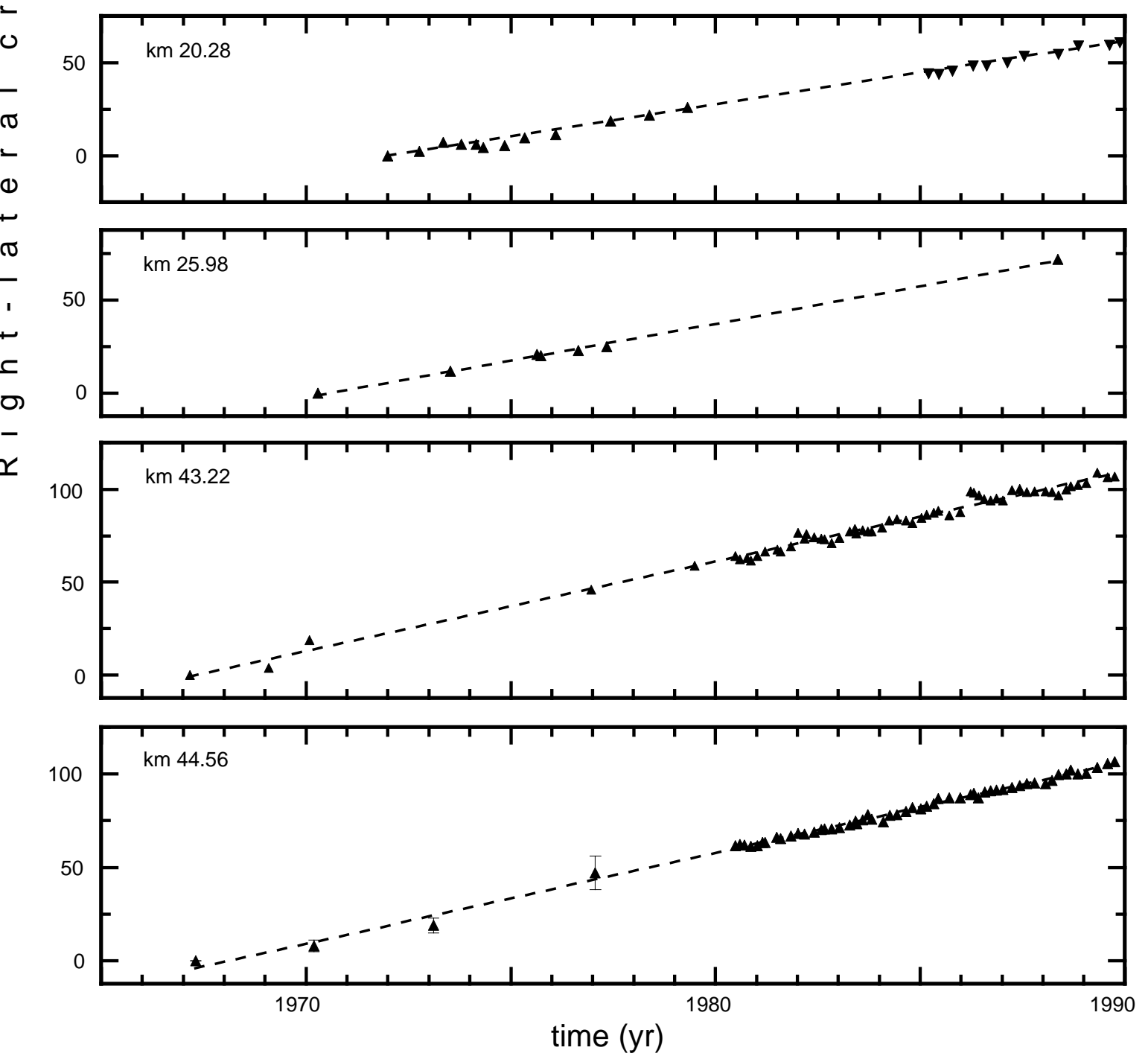


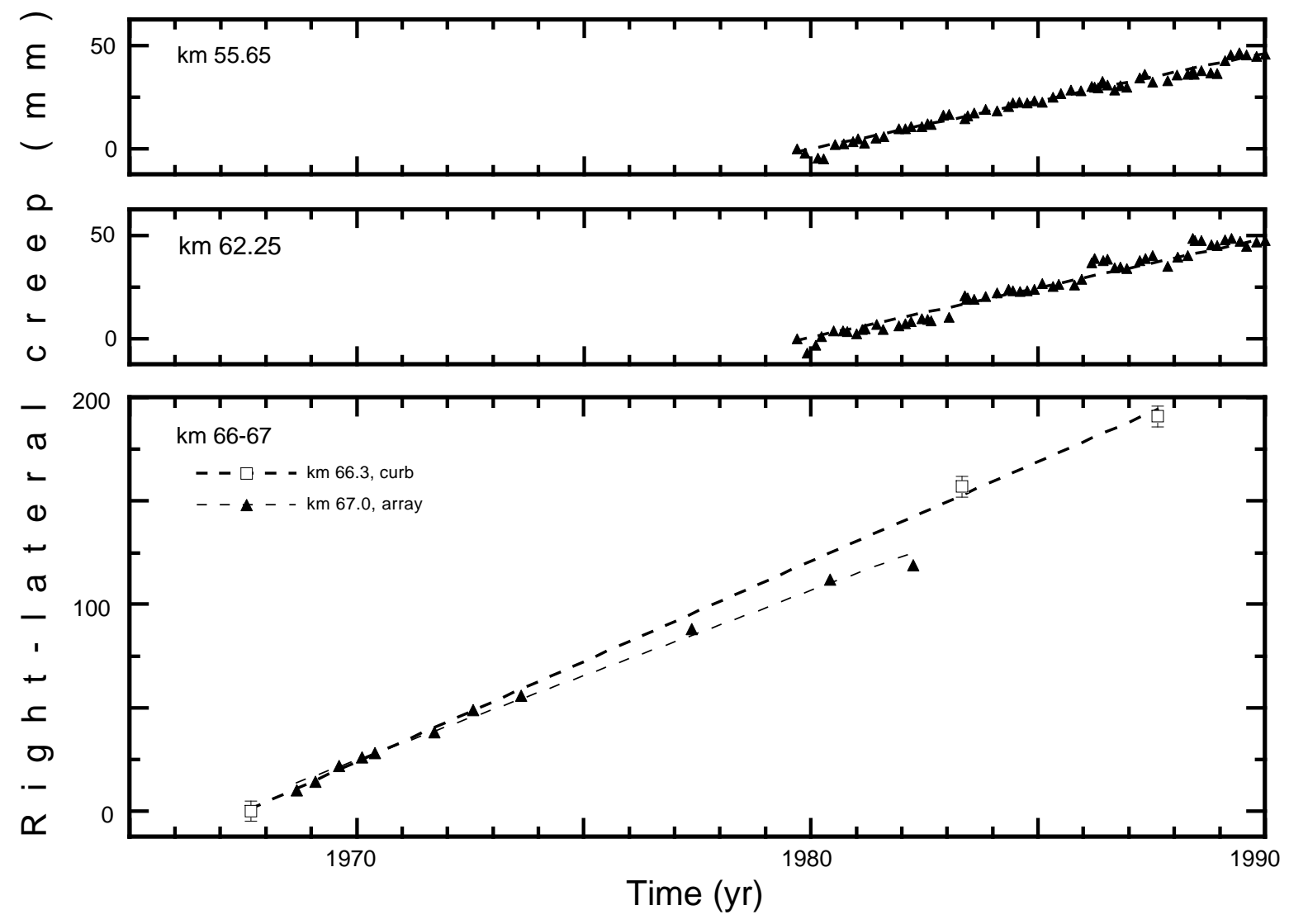

Figure 3 (continued) 
Table 1. Right-lateral creep rates on the Hayward Fault

\begin{tabular}{|c|c|c|c|c|c|c|c|c|}
\hline \multirow{2}{*}{\multicolumn{2}{|c|}{$\begin{array}{l}\text { Dist- } \\
\text { ance }^{1} \text { Item } \\
\mathrm{km} \mathrm{code}\end{array}$}} & \multicolumn{2}{|c|}{$\begin{array}{c}\text { Creep } \\
\text { rate }\end{array}$} & \multicolumn{2}{|c|}{$\begin{array}{l}\text { Item Error } \\
\text { Age in age }\end{array}$} & \multirow[b]{2}{*}{$\mathrm{T}$ (initial) } & \multirow[b]{2}{*}{$\mathrm{T}$ (final) } & \multirow[b]{2}{*}{ Comment $^{3}$} \\
\hline & & $\mathrm{mm} / \mathrm{yr}$ & \pm & $\mathrm{yr}$ & \pm & & & \\
\hline 1.82 & $\mathrm{D}$ & 5.1 & 0.1 & 25 & 0.002 & 1968.333 & 1993.058 & Point Pinole Regional Shoreline (PPRS), USGS $(\mathrm{N}=2)$ \\
\hline 1.82 & A & 5.0 & 0.3 & 12 & 0.002 & 1968.333 & 1980.459 & PPRS, HB82 (N=12) \\
\hline 1.90 & $\mathrm{C}$ & 5.0 & 0.2 & 39 & 0.5 & 1950.5 & 1989.836 & Banks Dr, NW curb \\
\hline 4.49 & A & 4.7 & 0.3 & 9 & 0.002 & 1980.610 & 1989.596 & Contra Costa College, SFSU \#17 (N=42) \\
\hline 4.50 & $\mathrm{C}$ & 4.5 & 0.6 & 34 & 1 & 1954 & 1988.415 & El Portal School, NW fence \\
\hline 5.12 & $\mathrm{C}$ & 4.4 & 0.4 & 45 & 0.5 & 1943.5 & 1988.415 & Bowhill Ln, NW curb \\
\hline 7.25 & $\mathrm{~T}$ & 5.5 & 0.3 & 7 & 0.1 & 1975.1 & 1982.200 & RICHMOND net, Prescott \& Lisowski [1983] $(\mathrm{N}=10)$ \\
\hline 8.36 & $\mathrm{C}$ & 5.7 & 0.2 & 25 & 0.2 & 1964.8 & 1990.068 & Olive Av, NW curb \\
\hline 12.93 & $\mathrm{C}$ & 6.0 & 1 & 51 & 2 & 1919 & 1969.96 & San Pablo tunnel centerline (600-m spacing); EBMUD \\
\hline 14.96 & $\mathrm{C}$ & 5.8 & 0.2 & 80 & 2 & 1910 & 1990.068 & Marin Av, SE curb (may include landslide component) \\
\hline 17.82 & $\mathrm{~T}$ & 4.7 & 0.1 & 22 & 0.002 & 1966.912 & 1988.41 & STADIUM net, USCGS \& USGS $(\mathrm{N}=5)$ \\
\hline 17.97 & $\mathrm{~A}$ & 4.9 & 0.2 & 19 & 0.002 & 1973.271 & 1992.666 & Prospect St, DJR \& this study \\
\hline 18.43 & $\mathrm{C}$ & 4.1 & 1.3 & 44 & 0.4 & 1946.4 & 1990.068 & Dwight Wy, NW curb, ave. of extreme interpretations \\
\hline 18.44 & . A & 3.9 & 0.8 & 9 & 0.65 & 1983.15 & 1992.615 & Dwight Wy, DJR \& USGS \\
\hline 20.00 & $\mathrm{C}$ & 4.4 & 0.5 & 39 & 0.8 & 1927.3 & 1966.036 & Claremont water tunnel, average of wall offsets, EBMUD \\
\hline 20.00 & $\mathrm{~A}$ & 4.6 & 0.3 & 5 & 0.002 & 1968.142 & 1973.047 & Claremont water tunnel, EBMUD \\
\hline 20.28 & $\mathrm{D}$ & 3.4 & 0.1 & 18 & 0.002 & 1971.989 & 1989.620 & BART tunnel, south bore; BART \& this study $(\mathrm{N}=22)$ \\
\hline 20.84 & - A & 3.8 & 0.3 & 20 & 0.002 & 1974.258 & 1994.118 & Broadway Bl, City of Oakland \& this study \\
\hline 23.71 & $\mathrm{C}$ & 2.7 & 0.3 & 55 & 1 & 1939 & 1994.115 & Montclair Park, SE fence \\
\hline 23.84 & - $\mathrm{C}$ & 3.0 & 0.3 & 39 & 0.1 & 1948.9 & 1988.361 & Medau Place, NW curb \\
\hline 23.85 & $\mathrm{C}$ & 3.0 & 0.2 & 39 & 0.1 & 1948.9 & 1988.361 & Medau Place, SE curb \\
\hline 23.91 & $\mathrm{C}$ & 3.1 & 0.2 & 38 & 0.1 & 1950.3 & 1988.361 & La Salle Av, NW curb \\
\hline 23.92 & $\mathrm{C}$ & 2.7 & 0.2 & 38 & 0.1 & 1950.3 & 1988.361 & La Salle Av, SE curb \\
\hline 25.98 & $\mathrm{D}$ & 4.0 & 0.1 & 18 & 0.002 & 1970.290 & 1988.358 & Lincoln Av, City of Oakland \& USGS, L91 (N=7) \\
\hline 27.81 & A & 3.7 & 0.2 & 14 & 0.002 & 1974.274 & 1988.358 & 39th Av, City of Oakland \& USGS, L91 \\
\hline 27.82 & $\mathrm{C}$ & 3.5 & 0.6 & 58 & 9.5 & 1930 & 1988.361 & 39th Av, EBMUD reservoir, NW fence \\
\hline 33.39 & $\mathrm{C}$ & 5.3 & 0.3 & 24 & 0.002 & 1964.762 & 1988.361 & Encina $\mathrm{Wy}, \mathrm{SW}$ curb \\
\hline 41.11 & $\mathrm{C}$ & 5.1 & 0.2 & 23 & 0.06 & 1967.21 & 1990.107 & 167 th Av, SE curb \\
\hline 43.22 & $\mathrm{C}$ & 5.1 & 0.3 & 62 & 0.5 & 1930.5 & 1992.019 & Rose St, NW curb; City of Hayward $(\mathrm{N}=5)$ \\
\hline 43.22 & A & 5.0 & 0.1 & 25 & 0.002 & 1967.167 & 1992.019 & Rose St, City of Hayward \& this study $(\mathrm{N}=7)$ \\
\hline 43.22 & A & 4.9 & 0.1 & 9 & 0.002 & 1980.482 & 1989.748 & Rose St, SFSU \#13 (N=55) \\
\hline 43.62 & A & 5.0 & 0.2 & 25 & 0.002 & 1968.107 & 1992.751 & Simon St, City of Hayward \& this study $(\mathrm{N}=4)$ \\
\hline 44.56 & $\mathrm{C}$ & 5.0 & 0.3 & 45 & 0.7 & 1922.5 & 1967.5 & D-St, NW curb \\
\hline 44.56 & $\mathrm{D}$ & 4.8 & 0.8 & 10 & 0.0 & 1967.301 & 1977.066 & D-St, deflection nails, City of Hayward \\
\hline 44.56 & A & 4.9 & 0.1 & 9 & 0.002 & 1980.479 & 1989.748 & D-St, SFSU \#12 (N=55) \\
\hline 44.72 & A & 4.3 & 0.3 & 22 & 0.002 & 1971.186 & 1993.068 & City of Hayward \& this study $(\mathrm{N}=4)$ \\
\hline 45.64 & - $\mathrm{C}$ & 4.7 & 0.2 & 33 & 0.5 & 1959.5 & 1992.809 & Palisade St, NW sidewalk centerline, this study \\
\hline 45.64 & - A & 4.7 & 0.4 & 16 & 0.002 & 1977.074 & 1992.809 & Palisade St, City of Hayward \& this study $(\mathrm{N}=2)$ \\
\hline 45.65 & $\mathrm{C}$ & 4.7 & 0.2 & 29 & 0.5 & 1959.5 & 1988.454 & Palisade Street, SE curb \\
\hline 50.15 & $\mathrm{D}$ & 4.4 & 0.2 & 23 & 0.002 & 1970.077 & 1992.866 & Woodland Av, City of Hayward \& this study $(\mathrm{N}=5)$ \\
\hline 54.45 & $\mathrm{~T}$ & 5.3 & 0.3 & 16 & 0.5 & 1965 & 1981 & UNION net, Prescott \& Lisowski [1983] (N=6) \\
\hline 55.65 & A & 4.7 & 0.1 & 10 & 0.002 & 1979.729 & 1989.596 & Appian Wy, SFSU \#2 (N=57) \\
\hline 58.85 & $\mathrm{C}$ & 5.5 & 0.4 & 33 & 0.5 & 1954.5 & 1987.115 & Shinn Station, guardrail (now destroyed) \\
\hline 58.87 & $\mathrm{C}$ & 5.3 & 0.3 & 27 & 0.5 & 1960.5 & 1987.115 & U. S. Gypsum warehouse, NW fence \\
\hline 59.09 & $\mathrm{~A}$ & 5.7 & 0.8 & 5 & 0.002 & 1983.759 & 1988.568 & Gilbert Av, WB87 (N=9) \\
\hline 61.64 & $\mathrm{C}$ & 5.2 & 0.3 & 18 & 0.2 & 1968.8 & 1987.232 & Fremont Senior Center, SE curb \\
\hline 62.24 & C & 5.3 & 0.2 & 28 & .56 & 1964.73 & 1993.041 & Rockett Dr, NW curb \\
\hline 62.25 & $\mathrm{~A}$ & 5.5 & 0.1 & 10 & 0.002 & 1979.729 & 1989.599 & Rockett Dr, SFSU \#1 (N=57) \\
\hline 63.10 & $\mathrm{C}$ & 8.9 & 0.3 & 47 & 0.3 & 1940.3 & 1987.636 & Union St, NW fence of warehouse \\
\hline 63.12 & $\mathrm{C}$ & $>8.5$ & 0.3 & 66 & 0.9 & 1921.9 & 1987.636 & Union St, NW wall of warehouse \\
\hline 63.21 & $\mathrm{C}$ & $>8.5$ & 0.6 & 96 & 0.1 & 1869.7 & 1965.685 & Irvington, railroad tracks; Southern Pacific survey data \\
\hline 66.29 & $\mathrm{C}$ & 9.5 & 0.3 & 20 & 0.1 & 1967.7 & 1987.636 & Camellia Dr, NW curb, L91 \\
\hline 67.02 & A & 8.2 & 0.2 & 14 & 0.1 & 1968.7 & 1982.3 & South Grimmer B1, HB82 $(\mathrm{N}=11)$ \\
\hline \multicolumn{9}{|c|}{${ }^{1}$ Distance measured along fault from San Pablo Bay shoreline using Lienkaemper [1992] } \\
\hline \multicolumn{9}{|c|}{$\begin{array}{l}{ }^{2} \text { Codes: A, angle change surveyed across fault. Multiple observations are time regressed; C, cultural feature surveyed. } \\
\text { Offset computed by multiple linear regression (MLR); D, Deflection monuments in linear array. Offset computed by } \\
\text { multiple linear regression; T, trilateration array. Creep rate derived from line length changes }\end{array}$} \\
\hline \multicolumn{9}{|c|}{$\begin{array}{l}{ }^{3} \text { Comment notes: BART, data of Bay Area Rapid Transit district; analysis, this study; DJR, data of D.J. Russell, } \\
\text { written communication, 1992; analysis, this study; EBMUD, data of East Bay Municipal Utilities District; analysis, } \\
\text { this study; HB82, Harsh \& Burford [1982]; analysis, this study; L91, Lienkaemper and others [1991]; N, number of } \\
\text { observations; SFSU \#1, San Francisco State University array number [Galehouse, 1995]; WB87, Wilmesher and } \\
\text { Baker [1987] data; analysis, this study. }\end{array}$} \\
\hline
\end{tabular}

